\title{
The 2014-16 Global Commodity Price Declines and Sub-Saharan Africa's Real Economy: Analysis for Sustainable Development
}

\author{
Ashford C. Chea ${ }^{1}$ \\ ${ }^{1}$ Department of Accounting, Finance, and Economics, The Tyrone Adam Burroughs, School of Business and \\ Economics, Benedict College, 1600 Harden Street, Columbia, SC 29204 USA \\ Correspondence: Ashford C. Chea, Department of Accounting, Finance, and Economics, The Tyrone Adam \\ Burroughs, School of Business and Economics, Benedict College, 1600 Harden Street, Columbia, SC 29204, USA
}

Received: December 10, 2017

Accepted: January 28, 2018

Online Published: January 31, 2018

doi:10.5430/bmr.v7n1p27

URL: https://doi.org/10.5430/bmr.v7n1p27

\begin{abstract}
The purpose of the article was to ascertain any unfavorable effect of the global commodity price declines on sub-Saharan Africa's (SSA) productive sectors. The findings suggest that the global commodity price declines impacted SSA economies in term of trade, growth link, prices, and liquidity. The conclusion derived from the findings is that African economic output was unfavorably impacted significantly, albeit at varying degrees.
\end{abstract}

Keywords: Global, Commodity, Declines, Sub-Saharan Africa, Impact, Economic, Growth

\section{Introduction}

\subsection{Background of SSA Economic Growth before the Global Commodity Price Declines}

SSA enjoyed strong economic growth of 5 percent in 2014 driven by robust investment and private consumption (Regional Economic Outlook April 2015). Benefiting from the high commodity prices prior to 2014, the East Africa sub-region produced a solid growth momentum. Growth in West Africa was robust throughout 2013. In Southern Africa, South Africa performed poorly according to the IMF, which cited a list of local challenges constraining growth, including labor unrest. (African Development Bank Statistics Department, 2013). Central Africa grew an average of 5.6 percent, reflecting modest resilience to external headwinds (African Development Bank, 2014).

However, economic growth declined slowly from the year before as oil exporting economies began to adjust to the declining global oil prices. Among SSA's main trading partners, prospects for growth in Western Europe remain low at best. Likewise, the U.S. dollar has strengthened substantially relative to the euro. This has strong implications for the region, where some economies have official pegs to the eurozone currency (Regional Economic Outlook April 2015).

The paper starts with a historical backdrop of the state of the SSA economies before the beginning of the global commodity price declines in 2014. It then presents an analysis of the transmission mechanisms of the crisis and its effect on the region. A discussion of policy reaction to the external shocks by policymakers is also outlined. The paper ends with an analysis of the outlook and growth prospects of SSA economies for the medium and long-term.

\subsection{Background of the Problem}

China enormous economic output is moderating, and the sources of that growth are shifting from public investment and manufacturing exports to local consumption. This change is impacting the global economic dynamics-but particularly commodity-exporting economies in SSA. Economic growth in SSA, which stands between 5 to 6 percent during the previous twenty years, declined less than 4 percent in 2015 and is forecasted to slow down still in 2016 (Chen and Nord, 2016).This unfavorable external headwind is made worse by insufficient fiscal space that policymakers have to counter the decline in economic activity. In most instances, surpluses accumulated from good economic times have been relatively insufficient, and the fiscal space is decreasing very fast (Regional Economic Outlook, October 2015). The collapse in hydrocarbon prices beginning 2014 is the most recent of several in the past thirty years. After four years of relative stability and growth, oil prices began a slide in June 2014. The deterioration in oil prices from $\$ 100$ to $\$ 50$ per barrel ushered in the end of an oil boom that started in the early 2000s (Baffes et al., 2015).

As a consequence economic activity in SSA in 2015 declined to its lowest level in 15 years. The main culprit 
associated with the decline happened to be the unprecedented deterioration in raw material prices (Regional Economic Outlook April 2016). Additionally, for those economies depending on global partners for funding, international capital conditions are rapidly becoming unfavorable. The forecasted interest rate policy reversal upward by the Federal Reserve Bank in the United States has already changed the environment of low costs of capital (Regional Economic Outlook October 2015). Future growth in SSA economies will, for the most part, depends on their capacity to successfully diversify towards highly productive manufacturing sectors. Accomplishing these goals requires increasing both public and private investments in key growth catalysts and drivers such as physical and human capital (African Development Report, 2015).

\subsection{Objectives of the Paper}

The objectives of the article were to systemically investigate and analyze the following: (1) the worldwide commodity price deteriorations and its effect on SSA's real economy; (2) reaction of SSA governments to the crisis; (3) medium and long-term outlook; and (4) implications and recommendations for future growth.

\section{Research Method}

This paper relied on the literature review of the current articles focusing on the worldwide commodity price slowdown and its effects on SSA real economy. The author filtered sources by "global commodity price slowdown and SSA real sector", and by numerous variant of keywords, focusing specifically on SSA real economy (Chea, 2017). Source documents included empirical studies, empirical reports, and work from specialized journals. Since the literature relating to the global commodity price declines is voluminous, the researcher applied several decision rules in choosing articles. First, the author selected mostly sources published from 2012 to 2016, except where articles were needed for their historical perspectives. Second, he included, in order of priority: refereed and empirical research articles, reports, and other relevant literature on current trends in the global economy and trade flows to SSA (Chea, 2017). Different strategies were executed to evaluate sources that were included in this paper. All materials were then categorized by keywords such as global, commodities, prices, declines, impact, sub-Saharan Africa, productive sectors, growth and development for the purpose of analysis. As a result, all of the referenced sources provided the data and information from which outcomes (i.e. evidence and conclusions) were drawn. To highlight some background perspectives on the global commodity prices deterioration and its impact of SSA real economy, the author began with the review of the current analysis of the slowdown of the international commodity prices and the transmission mechanism to SSA productive economy.

\section{Literature Review}

\subsection{Global Commodity Price Slowdown and the Transmission Channels to SSA Real Economies}

Declining global commodity prices impacted SSA economies negatively through several channels. The four major channels are:

1. Growth link: the slow down reduces economic growth in low-income economies.

2. Trade: the decline translates into lower SSA export revenues and trade credits.

3. Prices: the unfavorable income effect on commodity-dependent countries, in respect to lower terms of trade associated with declining natural resource prices, negatively impact national savings.

4. Liquidity supply: deteriorating foreign reserves and sovereign-wealth funds led to a slowdown of credit supply to the region. 


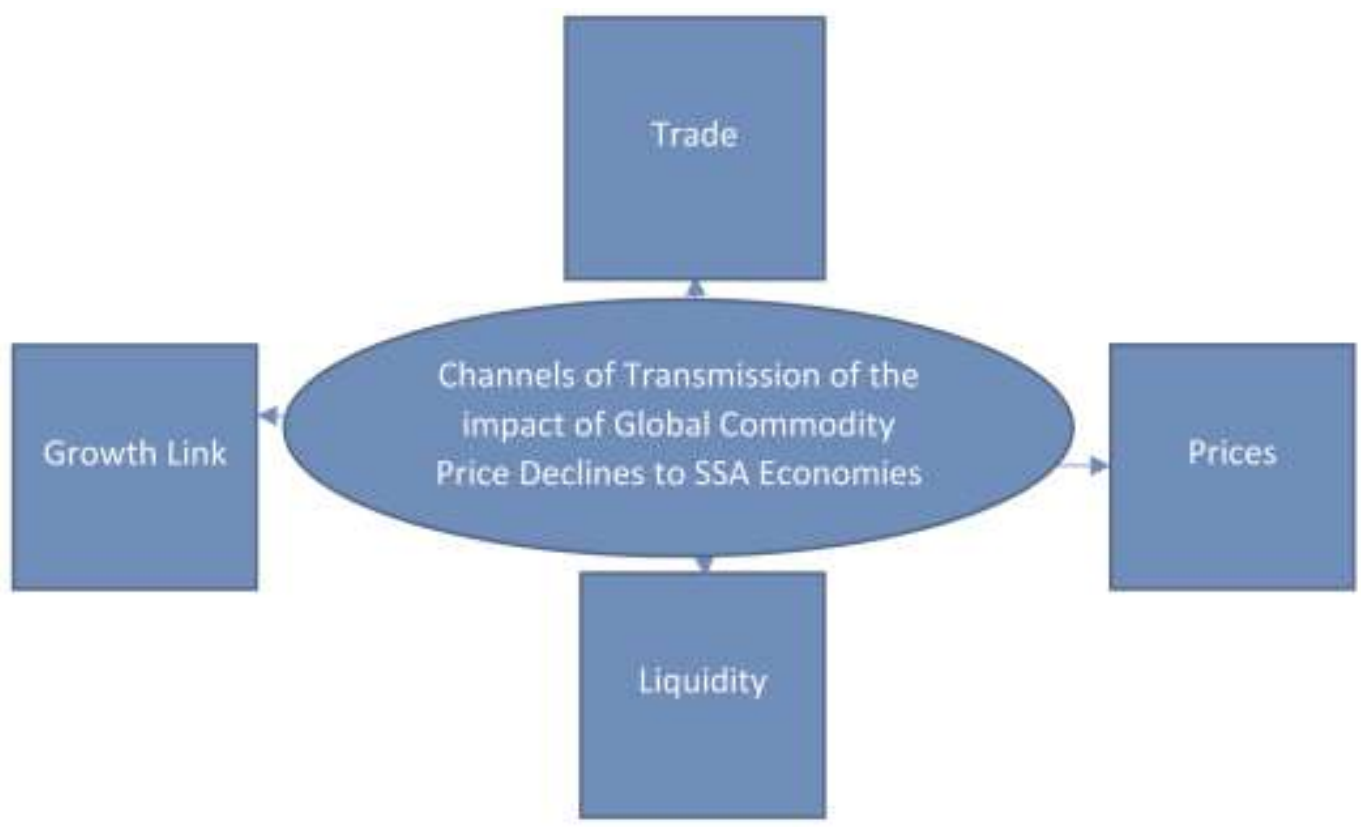

Figure 1. Transmission Channels of Impact

Author's Construct

Nonetheless, the outcome of China's moderating output and its restructuring on SSA economies is favorable. This is because the favorable effects derived from rebalanced economic activities exceed the unfavorable impacts. While declining commodity prices presented dangerous shocks to SSA's raw material exporters, the realignment of the Middle Kingdom does present some support, although incrementally. During the 2000s, China stood as SSA largest single trading partner (Sayeh, 2016).

The most crucial mechanism of transmission of spillover from China are the income effects on international trade and foreign investment. First, China's economic strategy will reduce global demand for SSA's exports. As its economic structure shifts towards a projected 4.6 percent by 2030, it could take in less SSA exports to drive its local domestic output. Second, feeble international demand is expected to translate into declining commodity prices. And third, as productive activities in the world second largest economy moderate, the pool of national savings is suddenly set to fall, leading to reduced financial outflows and funding for Chinese investments in SSA (Chandra et al., 2012; Dollar, 2013). A crucial pipeline for China's direct investment in the manufacturing sector in SSA is through special economic zones (SEZs). Of the 19 zones rectified by China as of 2011, four are located in SSA as listed below.

Table 1. Examples of Special Economic Zones by Country and Sector

\begin{tabular}{ll}
\hline Zambia & $\begin{array}{l}\text { Chambishi: copper and cobalt mining } \\
\text { Lusaka: garments, food, appliances, } \\
\text { tobacco, and electronics }\end{array}$ \\
\hline Nigeria & $\begin{array}{l}\text { Lekki: transportation equipment, } \\
\text { textile, light industries, home } \\
\text { appliances and telecommunications. }\end{array}$ \\
& $\begin{array}{l}\text { Ogun: construction materials and } \\
\text { ceramics, furniture, wood processing, } \\
\\
\text { medicine, computers, and lighting. }\end{array}$ \\
\hline Mauritius & Manufacturing and services. \\
\hline Ethiopia & $\begin{array}{l}\text { Oriental: electronic machinery, steel, } \\
\text { construction materials. }\end{array}$ \\
\hline
\end{tabular}

Source: Brautigam et al. (2011)

Chinese SEZ investments in SSA may turn out successful for several reasons. First, China has a long and good experience with its own SEZs. Second, the effort is part of a strategic government initiative with both political and socio-economic objectives. Third, the investments are fueled by enormous monetary and nonfinancial support from 
China. Finally, the special economic zones are profit-driven initiatives led by private economic actors (Brautigam et al., 2010, 2011).

\subsection{Impact of the Global Commodity Price Slowdown on SSA Real Economies}

SSA economic output in 2015 was projected to deteriorate to 3.4 percent, after a 5.1 percent growth in 2014 . Their growth rate in 2015 was projected to slow down to 2.6 percent relative to 5.9 percent in 2014 , and budget and external account positions declined significantly. Moreover, most currencies in the region have dropped in value significantly relative to the greenback. (Regional Economic Outlook April 2016).

The main catalysts for the slowdown in world economic growth since 2014 were (1) unfavorable global demand (2) deteriorating international commodity prices; (3) slower emerging economies growth; and (4) lower international trade volume. Increase in international inflation-adjusted gross domestic product and global merchandise exports was $1 \%$ less than forecasted. Metal prices and some agricultural products, such as grains, declined faster than estimated. In Angola, for example, the reduction in hydrocarbon prices decimated 50 percent of its revenue base (Chen and Nord, 2016). In Nigeria, oil exports contribute 70 percent of government revenues and 90 percent of foreign exchange inflows. As oil revenues evaporated, foreign exchange reserves declined, forcing the central bank to devalue the naira against the U.S. dollar by about 22 percent (Nwanma, 2015).

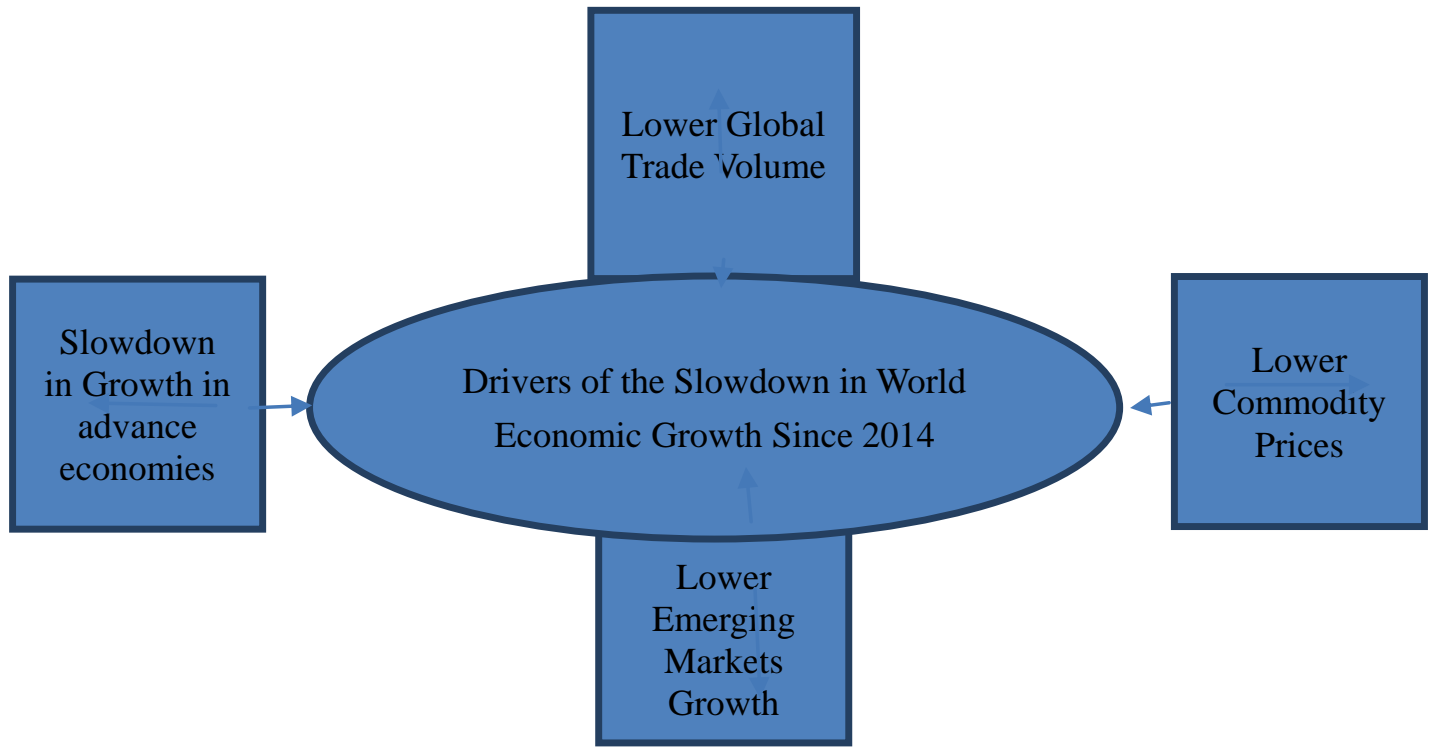

Figure 2. Drivers of World Economic Growth Slowdown

\section{Author's Construct}

Overall, as policy-makers carry out economic reforms, economic output will remain unfavorably impacted. Under existing measure, budget shortfalls in 2015 would deteriorate 5 percentage relative to GDP in many economies (Regional Economic Outlook, April 2015).

Unlike oil exporters, SSA's oil importers are beneficiaries in a significant way from the slowdown in commodity prices. For the typical oil-consuming economies, oil imports are worth 25 percent of all imports and 7 percent of the gross domestic product. Overall, the effect on oil importers' trade position in 2015 is also projected to be stable (Regional Economic Outlook, April 2015). Additionally, given that most SSA nations are net importers of food, the urgency has only increased as devalued local currencies make imports unaffordable. Some countries, like Nigeria, intervene by putting in place import substitution initiatives. Others seek to raise output growth by attracting foreign direct investment (Gregson, 2016). It is the economies with collapsing currencies that look the most foolhardy. For instance, the Zambian kwacha lost 40 percent of its value relative to the U.S. dollar last year (The Economist, 2016).

\subsection{SSA Economic Policymakers Response to the Global Commodity Price Meltdown}

During the past two decades, SSA countries achieved significant gains in national and per capita incomes, reduction in absolute poverty, and moderate improvement in health and education. Four key determinants helped propel the strong performance. First, there was an improvement in both economic and political governance in many countries. Second, there are more skilled technocrats and policymakers. Third, and related, economic and social policies have improved significantly leading to improvement in human capital. Fourth, during the past two decades world 
economic and financial conditions were generally favorable (Redelet, 2016).

Unfortunately, the above strong economic and social performance were upended suddenly by declining global commodity prices. This severe external shock and headwind have led to exchange rate pressures to which fiscal, exchange rate, and monetary policy responses by SSA economic policymakers have varied. Also, SSA economies have accepted market forces to determine the value their currencies, but most intervened to level out the external rates decline by reducing their limited foreign currency reserves. For instance, to mitigate these external pressures, many monetary policymakers increased their policy rates (Nigeria is a case in point) (Regional Economic Outlook, April 2016).

Specifically, commodity exporters are consolidating budget policy so as to counter the effect of the external headwinds. But budget shortfalls are forecasted to rise about a 3/4 percentage of output compared to 2014. In some economies, 2015 budget shortfalls are projected to remain stable from 2014 (see table 2). Likewise, interest rate policy has been consolidated in most economies, notably commodity exporting ones with currencies that have been hit severely (Regional Economic Outlook, April 2015).

Table 2. SSA Selected Macroeconomic Indicators

\begin{tabular}{|c|c|c|c|c|c|c|c|c|c|}
\hline & $2004-08$ & 2009 & 2010 & 2011 & 2012 & 2013 & 2014 & 2015 & 2016 \\
\hline \multirow{3}{*}{$\begin{array}{l}\text { Inflation, } \\
\text { end of } \\
\text { period }\end{array}$} & & & & $\begin{array}{l}\text { (Percent } \\
\text { change) }\end{array}$ & & & & & \\
\hline & $8.9 \%$ & 9.2 & 7.7 & 10.2 & 8.2 & 6.1 & 6.1 & 7.4 & 6.6 \\
\hline & & & & $\begin{array}{l}\text { (Percent } \\
\text { of GDP) }\end{array}$ & & & & & \\
\hline $\begin{array}{l}\text { Fiscal } \\
\text { balance }\end{array}$ & $1.7 \%$ & 0.3 & -3.4 & -1.1 & -1.8 & -3.0 & -3.3 & -3.7 & -2.9 \\
\hline $\begin{array}{l}\text { Of which: } \\
\text { Excluding } \\
\text { exporters }\end{array}$ & $-0.6 \%$ & -1.6 & -4.3 & -3.7 & -3.7 & -3.9 & -4.1 & -4.1 & -3.6 \\
\hline $\begin{array}{l}\text { Current } \\
\text { account } \\
\text { balance }\end{array}$ & $1.9 \%$ & 0.5 & -0.6 & -0.7 & -1.9 & -2.5 & -3.3 & -4.6 & -4.1 \\
\hline $\begin{array}{l}\text { Of which: } \\
\text { Excluding } \\
\text { oil } \\
\text { exporters }\end{array}$ & $-4.4 \%$ & -3.0 & -3.9 & -4.9 & -7.2 & -7.7 & -7.3 & -7.0 & -7.1 \\
\hline Reserve & & & & $\begin{array}{l}\text { (Months } \\
\text { of } \\
\text { imports) }\end{array}$ & & & & & \\
\hline coverage & 5.1 & 3.7 & 4.2 & 4.6 & 5.4 & 5.2 & 5.4 & $\mathrm{n} / \mathrm{a}$ & $\mathrm{n} / \mathrm{a}$ \\
\hline
\end{tabular}

Source: IMF, World Economic Outlook database, 2015.

Net oil exporting economies have initiated reforms to their policies in reaction to the global headwinds. As hydrocarbon price has plummeted, countries have adjusted downward significantly the oil price implicit in their 2015 budget projections. Along with declining projected oil prices policymakers have implemented reforms to adjust spending downward for public investment and wasteful subsidies (Regional Economic Report, April 2015).

As a consequence in the two years since prices for oil and industrial metals dropped into doldrums, many countries across SSA prioritized agriculture and agribusiness to diversify away from natural resource sectors and provide much-needed employment opportunities, especially among the youth population (Gregson, 2016). Similarly, the region's oil-exporters, particularly those with scarce buffers (Chad, Nigeria), started to rebalance due to the deterioration in oil prices. This restructuring caused lower economic growth than was previously projected. Fiscal 
and current account positions worsen materially in the region's oil-exporting economies (World Economic Outlook, April 2015). According to the World Bank, more than 70 percent of the region's economies carried out at least one reform. Moreover, the bank's Ease of Doing Business list ranks Mauritius $28^{\text {th }}$ out of 189 nations, with Rwanda coming in $46^{\text {th }}$ and Ghana $70^{\text {th }}$ (Nwanma, 2015).

\section{Contribution to Existing Knowledge and Limitation of the Analysis}

The value added to scientific knowledge of the paper lies in its analysis and insights derived thereof from two main issues, namely, the outlook for global commodity price and growth in SSA and the associated risks to the outlook. The analysis of the major issues is presented in order.

\subsection{Outlook for Global Commodity Prices and SSA Economic Growth}

SSA obtained high productivity output rate of 5 percent in 2014 stimulated by favorable foreign capital inflows in the mineral sectors and the physical infrastructure sectors (see Table 3). However, growth declined moderately from the earlier year as oil exporting countries began to respond to the declining international oil prices. Economic activity was projected to decline more in 2015. But with growth at 4.5 percent, SSA economies will be included on the list of the high-growth regions of the global economy (Regional Economic Outlook, April 2015). The outlook for global commodities demand growth falls short of that for total energy demand. This is because China, Brazil, India, and advanced economies are forecasted to significantly reduce their consumption of coal and oil (World Economic Outlook, April 2016).

Table 3. SSA Real GDP Growth

\begin{tabular}{llllllllll}
\hline & $2004-08$ & 2009 & 2010 & 2011 & 2012 & 2013 & 2014 & 2015 & 2016 \\
\hline SSA & $6.8 \%$ & 4.0 & 6.7 & 5.0 & 4.2 & 5.3 & 5.0 & 4.5 & 5.1 \\
Of which: Oil exporters & $9.2 \%$ & 6.9 & 8.5 & 4.7 & 3.7 & 5.7 & 5.8 & 4.5 & 5.2 \\
Of which: Nigeria & $8.6 \%$ & 9.0 & 10.0 & 4.9 & 4.3 & 5.4 & 6.3 & 4.8 & 5.0 \\
Middle-income & $5.0 \%$ & 0.2 & 4.6 & 4.7 & 3.4 & 3.6 & 2.7 & 3.3 & 3.7 \\
Of which: South Africa & $4.8 \%$ & -1.5 & 3.0 & 3.2 & 2.2 & 2.2 & 1.5 & 2.0 & 2.1 \\
Low-income states & $7.7 \%$ & 6.6 & 7.6 & 7.6 & 6.1 & 7.1 & 7.4 & 6.5 & 7.1 \\
Fragile states & $2.4 \%$ & 2.1 & 4.1 & 3.1 & 7.4 & 5.6 & 5.6 & 6.1 & 6.5 \\
World Economic growth & $4.9 \%$ & 0.0 & 5.4 & 4.1 & 3.4 & 3.4 & 3.4 & 3.5 & 3.7 \\
\hline
\end{tabular}

Source: African Economic Outlook, 2015.

Likewise, the outlook in 2016 remains grim for commodity exporters. Economic growth in hydrocarbon exporters is projected to slow to 2.2 percent (Regional Economic Outlook April 2016). Recent economic dynamics that brought about the plunge in global prices seem to have impacted oil markets in a sustainable way. Moreover, a long-standing global trend toward manufacturing technologies that consume less oil will continue to suppress increases in demand for SSA oil export (Buffes et al., 2015).

\subsection{Risks to the Outlook}

The recent international economic crises have demonstrated some of the risks and uncertainties involved in globalization and shown that economic liberalization must be accompanied by due attention to sound macroeconomic fundamentals and good governance (Harris, 1999). Such due diligence to the macroeconomic underpinning may focus on declines in commodity prices and its impacts on GDP growth rate, aggregate income, levels of employment, and perhaps domestic demand. Also, attention should be paid to the impacts on import activities and prices. Additionally, domestic price levels may be affected and currency valuations may be assessed to avoid a repeat. The danger that worldwide economic output could deteriorate more is not an understatement. Specifically, the economic slow- down, in China, India, Russia, Brazil, western Europe and Japan presents negative and unfavorable uncertainty to the global economic resurgence This has the ability to reduce external consumption for SSA's exports, and push regional economic activity down. Moreover, some SSA countries such as South Sudan, Chad, Nigeria, and Cameroon are dealing with security-related risks that are specific to the region. Such developments pose serious fiscal risks, cloud the political environment, and deter foreign investors (Regional Economic Report, April 2015). Softening growth in emerging markets such as Turkey, Israel, South Korea, and Mexico is another risk. This risk is particularly important for natural-resources exporters, which could suffer from weakening commodity prices. In addition, restructuring of growth drivers in China, from public investment to local 
consumption, will contribute to weakening the demand for investment-related commodities (Regional Economic Outlook, April 2014). Furthermore, SSA oil and commodity exporters planning to meet their financing needs through international borrowing could be susceptible to a reversal in investors' sentiment, due to a tighter U.S rates. Similarly, weakening of growth in the global markets could reduce demand for SSA exports (World Economic Outlook, April 2015).

In terms of the limitation of the study, the analysis of the problem and the findings derived are entirely informed by the systematic review of the literature of scholarly work. Hence the study lacks empirical data and the associated theoretical underpinning and conceptual framework. This does influence the empirical support of the findings and conclusions of the study.

\section{Implications for SSA Economic Policies}

The slowdown in global commodity prices has several implications for SSA economies. First, it is implied that the lack of diversification of exports may exacerbate negative terms of trade shock. Policies that encourage export diversification and integration into global value chains could be beneficial in tackling the global slowdown in the medium and long-term (Lakatos et. al, 2016). Second, emerging and frontier market countries in SSA should prepare to deal with the challenge of a tightening of global financial conditions by preserving their budget flexibility and by tightening relevant policies (Regional Economic Outlook, April 2014).

Third, structural reforms are required to promote and achieve long-term sustainable growth. For example, the lack of a developed and efficient infrastructure networks hampers SSA's competitiveness, productivity, and its participation in the global economy (African Development Report, 2015). Finally, falling global oil prices are also expected to strengthen growth among net oil importers by stimulating local consumer demand and reducing inflationary pressure (African Development Bank, 2015).

\section{Policy Recommendations for SSA Economic Policymakers}

Indeed, the recent headwinds SSA faces are a good indication of the strategic imperative to strengthen resilience against external shocks and global economic headwinds. Well thought-out structural measures, such as improving the quality of public infrastructure, would nurture the private sector and help to cushion and diversify the export base. (Sayeh, 2016). The answer to this problem is to build liquid and strong domestic financial markets that can channel resources efficiently and facilitate private economic growth (Ahmed, 2008).

Economic stability must be maintained while encouraging private sector growth, protecting investor rights, strengthening the rule of law, and reducing the cost of doing business to increase the efficiency in the economies. Also, human capital investment, including nutrition, health, and education, is critical to improving the productivity of the workforce (Thakoor and Wakeman-Linn, 2016).

In addition to spending cuts, governments must also find new sources of revenue. Policymakers will have to generate more revenues from non-oil economic activities (Ahmed, 2016). The current environment of low oil prices provides a unique opportunity to undertake politically difficult but strategically imperative reforms to eliminate remaining fuel subsidies (World Economic Outlook, April 2015).

In terms of handling the commodity prices slowdown, countries that adopt market-determined exchange rates should allow the exchange rates to move freely, deploying monetary policy adjustments as needed to contain runaway inflation. Countries lacking fiscal space that are hit hard by cyclical external demand shocks will likely need to seek external financing from donors or international financial institutions (Regional Economic Outlook, October 2012).

For countries that are not members of a currency union, intervention by central banks should be limited to mitigation of disorderly market movements. Fiscal adjustment is urgently needed to safeguard macroeconomic stability for the medium and long-term (Regional Economic Outlook, April 2015).

\section{Concluding Remarks}

SSA economies enjoyed post-crisis growth from 2009 to 2013. This strong economic performance was driven by high global commodity prices, low international interest rates, and strong emerging markets growth, including China. However, at the beginning of 2014, the global commodity markets started to decline, led by falling energy prices (African Development Bank, Statistics Department, 2014). Oil prices have deteriorated 50 percent, and global market forces have added to these episodes. For the medium to long term, oil prices are projected to be elevated but to stay below the prices of recent years (Regional Economic Outlook, April 2015).

The slowing of output growth in major emerging economies has been associated with lower commodity prices. Along with supply factors, the reduction in investment and (restructured) growth in China is depressing commodity 
prices (African Economic Outlook, 2016). Therefore, maintaining strong macroeconomic policy frameworks will be essential and fundamental as policymakers seek to address broader development challenges (Regional Economic Outlook, May 2013).

Policy reaction to declining oil prices, which are still being formulated in many countries, will be a function of a complex set of macroeconomic variables. These factors include the magnitude and duration of the terms-of-trade shock, the exchange rate system, budget and external cushions, balance sheet mismatches, exchange rate valuation, the output gap, and inflation (Husain et al, 2015). However, despite the current global commodity environmental challenges facing SSA, some regions have fared better than other. For example, in 2015, East Africa was again SSA's most dynamic economic region and is set to maintain its lead in 2016-17. In West Africa, growth slowed in 2015 due to the sharp fall in commodity prices. Nonetheless, other economies in the region obtained enhanced output in 2015 and their prospects for 2016-17 is favorable. In Central Africa, economic output deteriorated in 2015, and this trend will probably hold throughout 2016-17. Finally, economic activities in Southern Africa declined significantly in 2015 and is poised to resume in 2017 (African Economic Outlook, 2016).

\section{References}

African Economic Outlook. (2015). African economies to rebound in 2015, despite uncertain global conditions. Access Online: http://afdb.org/en/news-and-events/article/african-economies-t

African Economic Outlook. (2014). African economies grew by 3.9 percent GDP in 2014 amid global and regional shocks. Access Online: http://afdb.org/en/news-and-events/article/african-economies-...

Arezki, R. et al. (2016). World Economic Outlook: Commodity special feature. International Monetary Fund. Washington, D.C., April.

African Development Report. (2015). The way forward to achieving sustainable development in Africa. African Development Bank, Abidjan.

Ahmed, M. (2008). The next frontier. Finance \& Development, 45(3), 1-13. Access Online: http://imf.org/external/pubs/ft/fandd/2008/09/ahmed.htm.

Baffes, J.M., Kose, A., Ohnsorge, F., \& Stocker, M. (2015). Down the slide. Finance \& Development, December, 52(4). Access Online: www.imf.org/external/pubs/ft/fandd/2015/12/baffes.htm.

Barghini, T. (2016). African debt loads to grow again. Global Finance, April, 97.

Chea, A. (2017). The impact of the 2014-16 global commodity price declines on sub-Saharan African financial economy, International Journal of Economics and Finance, 9(6), 162-166. https://doi.org/10.5539/ijef.v9n6p162

Chen, W. and Nord, R. (2016). A fork in the road: China's new growth strategy could hurt Africa's commodity-dependent economies. Finance \& Development, June, 3(2), 28-29.

Harris, E. (1999). Impact of the Asian crisis on Sub-Saharan Africa. Finance \& Development, March, 36(1). Access Online: http://imf.org/external/pubs/ft/fandd/1999/03/harris.htm.

IMF (2008). Private capital flows to Sub-Saharan Africa: Financial globalization's final frontier?" in Regional Economic Outlook: Sub-Saharan Africa (Washington, D. C.)

Lakatos, C., Maliszewska, M., Osario-Rodarte, I., \& Go, D. (2016). China's slowdown and rebalancing: Potential growth and poverty impacts on Sub-Saharan Africa. World Bank Policy Research Working Paper 7666. World Bank Group. Washington, D.C., April. https://doi.org/10.1596/1813-9450-7666

Mallaby, S. (2016). Globalization resets: The retrenchment in cross-border capital flows, trade, and migration may be less dire than it seems. Finance \& Development, 53(4), 7-10.

Nguyen, A. D. M. et al. (2015). On the drivers of inflation in Sub-Saharan Africa. IMF Working Paper WP/15/189. International Monetary Fund. Washington, D. C. https://doi.org/10.5089/9781513583013.001

Nwanma, V. (2016). Commodity prices deal another blow. Global Finance, February, 53-54.

Radelet, S. (2016). Africa's rise: Interrupted? Finance \& Development, June, 53(1), 6-11.

The Economist (2016). Ante upped: Africa discovers the downside of foreign borrowing. April 2, 72-73.

World Economic Outlook (2015). Uneven growth: Short-and-long-term factors. International Monetary Fund. Washington, D. C., April. 